\title{
5E Learning Cycle in Practicing Written and Oral Argumentation Skills
}

\author{
*Valensa Yossyana ${ }^{1}$, Nadi Suprapto ${ }^{2}$, Tjipto Prastowo ${ }^{3}$ \\ ${ }^{1}$ Science Education Study Program, Postgraduate Program, The State University of Surabaya, Surabaya, Indonesia \\ 2,3Department of Physics, The State University of Surabaya, Surabaya, Indonesia
}

\begin{tabular}{|c|c|}
\hline (A) Check for updates open 0 access @C) (1) (-) & DOI : https://doi.org/10.46245/ijorer.v1i3.53 \\
\hline Sections Info & ABSTRACT \\
\hline & \multirow{9}{*}{$\begin{array}{l}\text { The argumentation ability plays an important role in the support of life } \\
\text { skills required in the } 21^{\text {st }} \text { century, but it has been recently found that this } \\
\text { ability among students remains at a low level. This situation has asked } \\
\text { for intervention to make the necessary skills improved. Thus, this study } \\
\text { aims to examine students' argumentation skills in written and oral senses } \\
\text { by implementing the } 5 \mathrm{E} \text { Learning Cycle in a classroom setting and to } \\
\text { analyze the effects of the implementation on ability the skills. The design } \\
\text { of this study was pre-experimental research using one group pretest- } \\
\text { posttest method. The learning materials used during the study were } \\
\text { syllabus, lesson plans, handouts, worksheets, and exercises. Meanwhile, } \\
\text { the ability of scientific argumentation skills was evaluated and assessed } \\
\text { using pretest-posttest given and interviews in the form of descriptive } \\
\text { questions and the corresponding guidelines. The results of the study are } \\
\text { here reported as three separate findings. Firstly, the application of the } 5 \mathrm{E} \\
\text { Learning Cycle in science learning allowed the students to practice their } \\
\text { scientific argumentation skills. Secondly, direct observations found that } \\
\text { most activities were well performed during classroom learning. Thirdly, } \\
\text { group discussions in the 5E Learning Cycle have a good contribution to } \\
\text { the students' scientific argumentation skills. }\end{array}$} \\
\hline & \\
\hline & \\
\hline & \\
\hline & \\
\hline & \\
\hline & \\
\hline & \\
\hline & \\
\hline
\end{tabular}

\section{INTRODUCTION}

Communication skills will be very much needed in the $21^{\text {st }}$ century. Written and oral communication skills are important skills that the students must have in the future because both of these abilities are critical abilities needed in various professions (Chan, 2011). The communication ability is one of the missions of science education that is useful (Kivunja, 2014; Kızılaslan, 2019; Larson \& Miller, 2011) so that the students can define phenomena/ problems around humans (Kiz1laslan, 2019).

The ability that is included in the category of communication is the ability to argue (Kurniasari, 2017). Arguments can be delivered both in the written and spoken form (Eemeren \& Henkemans, 2016; Kuhn et al., 2017; Tama, 2015). Argumentation is a form of communication that can be stated through media to provide views to convince others (Fauziya, 2016). Meanwhile, the definition of scientific argumentation is a statement given by someone which contains truth because it contains data and theories that are related and can support the statement. The argument is an attempt to build the truth because the claims given are supported by data, warrants (in the form of a relation between claims and data provided), backings that can be in the form of an appropriate theory, or qualifier (a special conditions where the claim applies) (Toulmin, 2003). Argumentation is a verbal, social, and rational activity aimed at convincing a reasonable critique of the acceptance of certain opinions by proposing one or more propositions designed to justify that point of view (Eemeren \& Henkemans, 2016). 
Scientific argumentation has an important role when it is introduced in learning. Introducing argumentation in learning to the students will be able to develop or enhance critical skills, the spirit of inquiry, contextual understanding, and the student academic performance (Faize et al., 2018). In particular, argumentation contributes to two of the four components of critical thinking, i.e the use of criteria and evidence to evaluate knowledge, and indispositions to reason-seeking and challenge authority (Jiménez-Aleixandre \& Puig, 2012). This is also supported by the existence of a significant contribution of argumentation in developing critical thinking with characteristics in the form of assessing information sources, evaluating arguments, producing arguments, and presenting them. (Roviati \& Widodo, 2019).

However, there are some facts about the ability of written and oral argumentation owned by the students. Research conducted by Cahyaningrum et al. found that the students' written argumentation skills were still low, this was evidenced by the test results which showed only 13 students (34.21\%) managed to pass, while 25 other students $(65.79 \%)$ did not pass the test. Cahyaningrum et al. stated several things that caused the low ability of the students' argumentation, i.e the students' lack of activeness and motivation while writing arguments and the students were less able to reveal supporting facts that could be used as a reinforcement for their arguments. (Cahyaningrum et al., 2018). In the National Center for Education Statistics, there are also reports of negligence of the evaluative standards in the students 'written arguments so that only about $25 \%$ of the students' argumentative essays provide strong reasons and supporting examples (National Center for Education Statistics, 2012). Hartidini et al. in her research, she revealed several things that became obstacles to students in writing arguments, i.e 1) the students were less trained in writing arguments independently, 2) the students had difficulty expressing ideas/ideas in writing arguments, this was because the students had difficulty distinguishing between facts and opinions that would be expressed in their written arguments, 3) the students' lack of understanding of the argumentation writing, 4) the learning strategies used by the teacher in practicing argumentation skills are less varied so that students are not interested and tend to feel bored (Hartidini et al., 2018). Furthermore, Faizah et al. through his observation showed that the students' argumentation skills, especially oral argumentation, were still low because only 7 out of 37 students could make a claim (Faizah et al., 2018). She stated that one of the causes was the lack of facilities (in the form of intervention/treatment during learning) to support the students to submit the arguments verbally.

The existence of these facts proves that the school needs to provide learning that can help the students to practice their written and oral argumentation skills. Arguments need to be taught from an early age because these activities rely on thinking activities, by practicing making arguments, one also practices critical and logical thinking because the arguments expressed must be accompanied by strong facts and evidences (Ni'amah et al., 2017). Encouragement is needed to design such interventions to improve the quality of the students' argumentation (Ferretti \& Lewis, 2019). This is because the ability of scientific argumentation is influenced by student involvement in argumentation activities during the learning process (Wahdan et al., 2017).

Lots of research has provided interventions to practice the students' scientific argumentation skills. Research on the comparison of physics learning outcomes in terms of oral and written argumentation abilities shows that student learning outcomes 
in oral argumentation ability classes are higher than student learning outcomes in written argumentation ability classes (Ulpa et al., 2014). Research conducted by Ulpa et al. is a Pre-Experimental Design study with the type of One-Shot Case Study, arguments scoring matrix is holistically adapted from Hand \& Choi (2010) so that the data obtained for oral and written argumentation are only quantitative data. Ulpa et al. used the oral argumentation ability approach and the written argumentation ability approach as a form of intervention given to the students.

This study aims to develop prior research using the 5E Learning Cycle as a learning model to practice students' arguments. Learning with the 5E Learning Cycle is inquirybased learning or uses scientific inquiry in building and finding knowledge so that this learning is student-centered (Kaniawati et al., 2015). The learning has several stages. These stages are engagement, exploration, explanation, elaboration, and evaluation (Kaçar, 2013). The 5E Learning Cycle model was chosen because it supports the students in practicing argumentation skills. The existence of group discussions can help the students in developing an explanation (Demircioglu \& Ucar, 2015). The learning cycle phase can produce arguments from the students by 67\% (Kulatunga et al., 2014). The students get positive experiences in understanding, developing, and applying arguments with the investigation of 5E (Chen et al., 2018).

On top of that, this study also observed the students' written and oral arguments. The students' arguments are being categorized based on the analytical framework of the quality of the scientific arguments developed by Erduran et al. (2004). Erduran et al. has developed methodological tools to extend the measurement of qualitative and quantitative outcomes from teaching and learning argumentation. There are several statements related to the research they carried out, i.e 1) their research describes how the coding of the whole class conversation which results in an argument profile that can be used as an indicator of improving learning implementation performance, 2) their research has described the potential of TAP (Toulmin's Argument Pattern) to explain the distribution of arguments in the lecture, 3) the scheme they developed has shown how the role of the teacher will be needed to move the conversation to be more inclusive of TAP with backings and arguments. In the research of Erduran et al., the framework is the development of Toulmin's Argument Pattern and is classified into 5 levels of argument quality. The five levels are 1) level 1, indicated by arguments containing simple claims, 2) level 2 , indicated by arguments containing claims and data, warrants or backings but do not have any rebuttal, 3) level 3, marked with arguments that contain a series of claims with data, warrants or backings as well as the existence of weak rebuttal, 4) level 4, marked with arguments containing claims (there can even be multiple claims) with an identifiable rebuttal and 5) level 5, marked with arguments that are extended in the presence of more than one rebuttal (Erduran et al., 2004).

\section{RESEARCH METHOD}

\section{General Background}

This research is a pre-experimental research design that has the characteristics of a group that is used only one class so that this research design does not have a control class. The Pre-Experimental design used was one group pretest-posttest. The design compares the two data (before and after treatment) in the same group (Ismail, 2018). 


\section{Place, Time, and Sample}

This research was conducted at a public high school in Surabaya. The time of the implementation was in the 2019/2020 school year, precisely in the even semester. The study population was the students of grade ten of Science subject. Meanwhile, the research sample was one class with 32 students. The sample was determined by using a purposive sampling technique or the determination of the sample with certain considerations.

\section{Instruments and Procedures}

There are several instruments and procedures used in this study. 1) Learning materials that support the learning process consist of a syllabus, lesson plan, handouts, worksheets, and question exercises. 2) To know the ability of the students' scientific argumentation in writing, the test technique (pretest and posttest) is performed. The test instrument used was a 6-item description of Newton's Law and the question was validated by the experts. To obtain the quantitative data to determine the increase in the students' scientific argumentation skills before and after the implementation of the 5E Learning Cycle, a modified scoring guideline from Robertshaw \& Campbell (2013) is needed to score the students' pretest and posttest (written argumentation). Meanwhile, to obtain the qualitative data in the form of the quality of students' written arguments, the analytical framework for the quality of arguments developed by Erduran et al. (2004). 3) To determine the ability of the oral scientific argumentation, an interview technique was carried out with the instrument used in the form of an interview guide regarding Newton's Law. To obtain the qualitative data in the form of the quality of students' oral arguments (interview results), the analytical framework for the quality of arguments developed by Erduran et al. (2004). 4) To determine the implementation of student activities during learning, observation sheets were used for three observers.

\section{Data Analysis}

Meanwhile, there are several data analysis techniques used in this study. 1) To determine the increase in students 'scientific argumentation skills before and after the implementation of the 5E Learning Cycle, several analyzes were carried out on the results of the students' pretest and posttest: a) The normality test is needed to find out the distribution of data on the student's pretest and posttest scores. The data normality test is measured with Shapiro-Walk using SPSS. Shapiro-Walk was chosen because it can test samples with small amounts up to 2000 (Si, 2015), b) After that, a different test of the ability of scientific argumentation is written on the results of the pretest and posttest results. The difference test is measured with the Paired T-Test through SPSS. Paired T-Test was chosen because this difference test was performed on a paired data which belongs to the same group, c) To find out the success rate of the 5E learning cycle, the N-Gain test is calculated manually on the pretest and posttest results. The criteria used for the calculation of N-Gain results are based on the criteria developed by Hake \& Reece (1999) 2) The quality of good scientific argumentation provided by the students through pretest-posttest answers, and interviews is qualified based on the analytical framework of the quality of argumentation developed by Erduran et al. (2004). The results of the written arguments in the form of frequency distribution tables for the quality of the students' arguments. Meanwhile, the results of the oral arguments in the form of interview transcripts were analyzed manually. This analysis is done by giving a code scientific argument component contained in the sentence sentences given 
by the students during the argumentation session. The coding was then analyzed using an analytical framework developed by Erduran et al. (2004) to find out the level of quality of the arguments given by the students. 3) The results of the student activities observation sheets during the learning process of the three observers were processed using the mode technique. The results of the mode value at each stage of the Learning Cycle are then calculated using the formula 1,

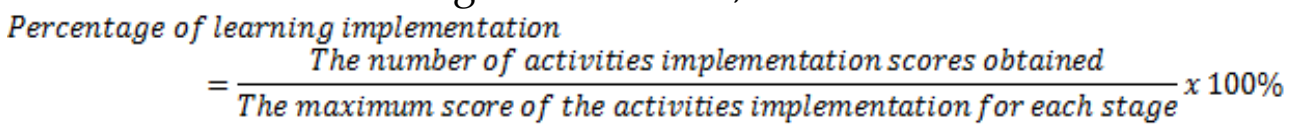

The results of these calculations are then adjusted to the criteria for the implementation of student activities in Table 1.

Table 1. Criteria for the percentage of student activities implementation.

\begin{tabular}{cl}
\hline Percentage Interval & \multicolumn{1}{c}{ Interpretation } \\
\hline $0 \%$ & None of the activities were carried out \\
$0 \%-25 \%$ & A small number of activities are carried out \\
$26 \%-50 \%$ & Nearly half of the activities were carried out \\
$50 \%$ & Half the activities are done \\
$51 \%-75 \%$ & Most of the activities carried out \\
$76 \%-99 \%$ & Almost all activities carried out \\
\hline $100 \%$ & All activities carried out \\
\hline
\end{tabular}

(Source: Riduwan, 2015)

\section{RESULTS AND DISCUSSION}

Analysis of The Improvement of Students' Scientific Argument Ability Before and After The Implementation of The 5E Learning Cycle

\section{- Normality Test Results}

The first normality test is performed to determine the distribution of the data to be examined. Normality test using Shapiro-Wilk through SPSS produces a significant value on the pretest result data of 0.159 and the significance value on the posttest result data of 0.293 . Both significance values indicate that the pretest and posttest results are normally distributed, this is because the significance value is greater than the $5 \%$ level of significance (Santoso, 2019).

\section{- Paired T-Test Results}

The test is conducted to determine whether there are differences in the students' written argumentation abilities between before and after learning with the $5 \mathrm{E}$ Learning Cycle. Paired Sample T-Test Test results show that the value of sig. (2-tailed) of 0,000 . This value is smaller than the alpha value of 0.05 or sig.(2-tailed) $(0,000)$ $<$ alpha (0.05). According to the testing criteria, if the value of sig. (2-tailed) is smaller than the alpha value then $H_{0}$ is rejected and $H_{1}$ is accepted (Hulu \& Sinaga, 2019) or in other words, there are differences in the ability of the students' written argumentation before and after learning with the 5E Learning Cycle. The Paired Sample T-Test also found a value of $\mathrm{t}$ count amounting to 33.47 while the table value (with alpha 5\%: $d f=31$ ) was 2.042. Based on the result, it is known that the value of count (33.470)> table (2.042) so that $H_{0}$ is rejected and $H_{1}$ is accepted (Hulu \& Sinaga, 2019). In other words, there are differences in the ability of the students' written argumentation before and after learning with the 5E Learning Cycle. 


\section{- N-Gain Results}

This test was conducted to determine the increase of the students' scientific argumentation skills in writing before and after the application of the 5E Learning Cycle. The calculation results obtained an N-Gain score of 0.56. Based on the N-Gain criteria developed by Hake \& Reece (1999), the score is in the medium category or it can be said that the students' scientific argumentation ability in writing before and after the application of the 5E Learning Cycle has increased at a moderate level.

\section{Analysis of The Students' Written Scientific Argument Ability}

The quality of the students' scientific arguments in writing spreads over several levels. There are five levels of argument quality developed by Erduran et al. (2004) based on Toulmin's Argument Pattern. Level 1 is the lowest level of the argument quality because in this level the arguments given by the students only contain simple claims, while level 5 is the highest because this level describes the arguments with complex components. The distribution of these qualities on each item of the pretest and posttest results is presented in the following table,

Table 2. Distribution of the quality levels of scientific arguments written.

\begin{tabular}{|c|c|c|c|c|c|c|c|c|}
\hline \multicolumn{3}{|c|}{ Level } & NA & 1 & 2 & 3 & 4 & 5 \\
\hline Number of Test & & & \multicolumn{6}{|c|}{ Percentage of Students } \\
\hline \multirow{2}{*}{1} & Pre & & 0 & 59 & 31 & 9 & 0 & 0 \\
\hline & Po & 0 & & 3 & 88 & 9 & 0 & 0 \\
\hline \multirow{2}{*}{2} & Pre & & 19 & 56 & 13 & 13 & 0 & 0 \\
\hline & Po & 0 & & 3 & 9 & 66 & 22 & 0 \\
\hline \multirow{2}{*}{3} & Pre & & 31 & 69 & 0 & 0 & 0 & 0 \\
\hline & Po & 0 & & 69 & 13 & 19 & 0 & 0 \\
\hline \multirow{2}{*}{4} & Pre & & 81 & 19 & 0 & 0 & 0 & 0 \\
\hline & Po & 0 & & 22 & 72 & 6 & 0 & 0 \\
\hline \multirow{2}{*}{5} & Pre & & 84 & 9 & 6 & 0 & 0 & 0 \\
\hline & Po & 0 & & 13 & 78 & 9 & 0 & 0 \\
\hline \multirow{2}{*}{6} & Pre & & 97 & 3 & 0 & 0 & 0 & 0 \\
\hline & Po & 3 & & 50 & 44 & 3 & 0 & 0 \\
\hline
\end{tabular}

*) NA = No Answer; Pre = Pretest; Po = Posttest

Based on Table 2, the low pretest results shown by the large number of the students who are categorized at a low level in the quality of argumentation shows that the students are less able to give good arguments and do not have enough knowledge in providing a suitable argument with the problem being raised. In her research, McNeill found that the quality of student argumentation was caused by several reasons, one of which was students' understanding of scientific content. She stated that if students do not understand the concept of science, then the student is unable to make a claim that is scientifically accurate or the student is unable to properly justify these claims (Mcneill, 2011). From Table 2, it can also be seen that there is an increase in the level of the quality of the students' scientific arguments from the low level in the pretest results to a higher level in the posttest results with more complex argumentation components. This can be seen by comparing the number of the students at the level of the argument for each item. The overall posttest results indicate that level 4 is the highest level that the students can achieve in making scientific arguments in writing. The quality of argumentation at level 4 is indicated by the existence of the claims (even allowing the 
existence of several claims), a rebuttal that can be identified, and feedback on the arguments given (Erduran et al., 2004).

\section{Analysis of The Implementation of The 5E Learning Cycle In Terms of Student Activities}

An increase in the ability of scientific argumentation that is known through the results of the pretest-posttest needs to be reviewed under the observation of the students' activities when carrying out the learning that applies the 5E Learning Cycle. The results of the observations of the students' activities which are carried out by the three observers are presented in Figure 1.

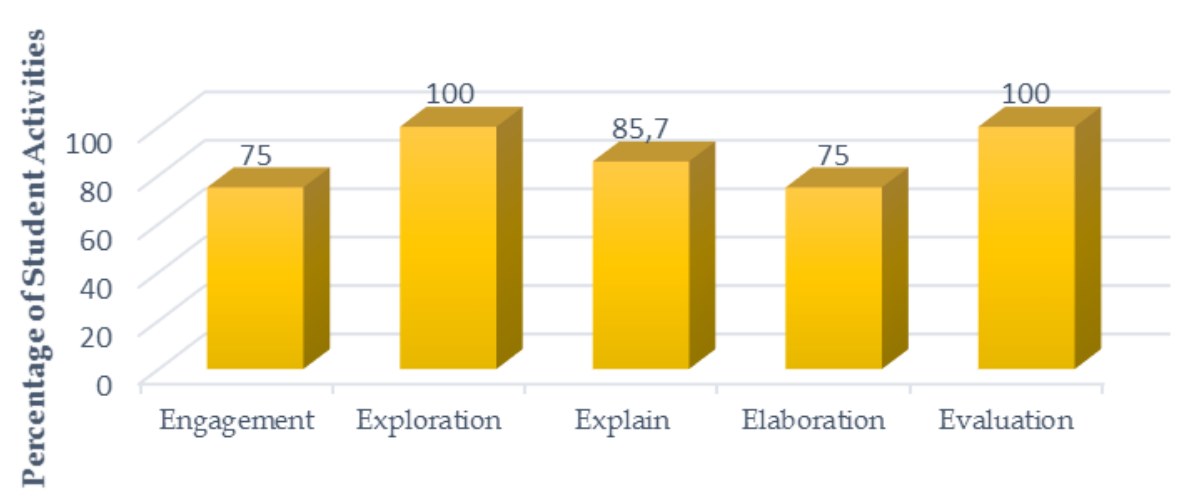

5E Learning Cycle

Figure 1. Observation results of student activities during 5E learning cycle.

Based on Figure 1, all student activities can be carried out in the process of exploration and evaluation. That is because the two processes get the maximum and highest percentage of the three other 5E Learning Cycle processes. The exploration process is the stage where the students try to solve the problems given by conducting some research activities such as formulating problems, making hypotheses, mentioning the research variables used, compiling research steps, conducting research, and collecting data so that in this case, the students can use the data as the evidence in compiling a scientific argument. Besides, at this exploration stage, the students also conduct data analysis that has been obtained previously. In the analysis process, the students are trained in groups to compile components of the written scientific argumentation based on the model/argument design. The model/design of the argument becomes important to show the students so the students can make a valid scientific argument. Showing students the criteria structure of an argument or a good explanation of an argument becomes one of the efforts that can support the focus of the student's argumentation in learning (Ryu \& Sandoval, 2012). Several studies have developed models/designs that can support the students to communicate their arguments (McNeill \& Krajcik, 2008; Sampson, 2014). The existence of the exploration stage carried out in groups makes the students able to exchange their ideas, correct each other's mistakes especially in the process of preparing arguments, and mutual knowledge building. Several studies have shown that group activities can introduce arguments because of the existence of the participation which is attended by the group members (Heng et al., 2015; McNeill \& Martin, 2011). Meanwhile, the evaluation process is a process that is done to find out whether the students have understood the 
concepts taught correctly, so in this case, the students need to answer several questions about the things they have learned during learning.

Furthermore, as can be seen from Figure 1, it is known that almost all student activities are carried out in the explaining process. This can be seen from the percentage of the students' activity which reached $85.7 \%$. The process of explaining in this case can be referred to as an argumentation session where a group of the students submits their oral arguments about the research results that they have obtained during the exploration process. The argumentation session is designed to allow students to learn to criticize the product (in the form of a conclusion, explanation, or argument), process (in the form of a method), and context (in the form of a theoretical or empirical basis) of an investigation (Walker \& Sampson, 2013). The results of the observation show that the students can deliver the claim correctly, the suitable data with the guided questions given previously, and can respond to another claim from the students who speak in front of the class by asking questions or giving feedback. However, the students show the lack of the expected ability when trying to convey the warrants, backings, qualifier, and rebuttal of the arguments given by the students who speak in front of the class so that in this case, the teacher's direction is needed so that the students can provide the components of the argument. This statement is supported by the research conducted by Heng et al. who found out that the students often delivered simple arguments consisting only of the claims and the data, the students were weak in providing other argumentation components such as warrants, backings, and qualifier (Heng et al., 2012). Moreover, only a few students of the group members who can convey their ideas during the implementation of this argumentation session. Such a thing may happen because the students do not have the depth of understanding or the skills to build strong arguments, they often find it difficult to provide support such as the reasons why they choose certain data as evidence in their arguments (Walker \& Sampson, 2013).

Figure 1 also shows that most of the students' activities take place in the initial process of engagement and elaboration process. This is indicated by the value of $75 \%$ of the students' activeness. However, both of these processes get the lowest percentage than the other three 5E Learning Cycle processes. The engagement process aims to center the focus of the students' attention on the topic of the material to be discussed and increase the students' curiosity during learning. The engagement process is also able to increase the students' curiosity during learning because the teacher provides a stimulus using video/media that is following the material being discussed (Putri et al., 2019). The teacher tries to link between the knowledge that the students have and current knowledge by giving them several questions, showing them some phenomena in everyday life related to the material, and so on.

Meanwhile, the elaboration process is a process that requires the students to practice the new knowledge that they have already gained and applies it to the new similar problems. The elaboration process is a process to explain, develop, and enrich the answers or ideas that have been given to the students (Ernawati et al., 2019). In this process, the students are trained again with the kind of assignments that requires the students to make written scientific arguments individually. However, it was found that the students were more able to make arguments in groups (i.e. when carrying out the exploration process) rather than making arguments individually. This can be seen from the results of the students' assignments between making written arguments in groups and individually. By working individually, only a few students can write the argument 
components correctly and suitable for the problem being raised. These results are supported by the research conducted by Heng et al. who found out that the students in groups tended to be more able to produce arguments with more complex components than the students who work individually (Heng et al., 2015).

\section{Analysis of The Students' Oral Scientific Argument Ability}

The analysis of the oral scientific argumentation skills was done manually. The dialog in the argument session video was recorded and transformed into a transcript of a written conversation. There were three arguments session based on the material discussed, they are Newton's 1st Law, Newton's 2nd Law, and Newton's 3rd Law. After that, we continued with the process of coding the component arguments contained in the opinion given by the students. These are the examples of arguments given by some students in the Newton's 2nd Law argumentation session,

$T$ : I have stones and paper that I have kneaded, then I drop both of them together. Which object will first reach the ground?

$S_{A}:$ The stone will be the first to reach the ground, ma' am

$S_{B}:$ Aren't these two objects going to fall together?

$T$ : Explain the reason, please!

$S_{B}:$ The two objects will fall together because both objects are affected by the same gravitational acceleration which is the acceleration of the Earth's gravity. So when the objects are released on the Earth's surface, they will experience the same acceleration even though the mass they have is different.

$T$ : Then what if I replace the two objects with paper. The first paper is still a sheet, while the second paper is paper that has been kneaded? Which paper reaches the ground first?

$S_{B}:$ If the phenomenon is like that then the crumpled paper will reach the ground first.

$T$ : Why?

$S_{B}$ : This is because when the paper in the form of sheets dropped, it will be hampered by air and fall longer. Acceleration of gravity applies if we ignore air resistance. But if the two papers are dropped in a vacuum, then both papers will fall simultaneously.

The argument given by the $S_{A}$ student is a level 1 argument because she only gives simple claims without data or warrants, and her argument does not contain any rebuttal. $S_{A}$ is not able to build strong arguments so that $S_{A}$ is only able to make claims. This is similar to Walker \& Sampson's finding that students often have difficulty providing reasons or support for their claims (Walker \& Sampson, 2013). Meanwhile, the argument given by $S_{B}$ students is a level 4 argument because it provides a rebuttal in the form of "aren't these two objects going to fall together?" Then he shows the sentence "the two objects will fall together" as the claim and "both objects are affected by the same gravitational acceleration which is the acceleration of the Earth gravity. So when the objects are released on the Earth's surface, they will experience the same acceleration even though the mass they have is different" as the data. After that, he returned to claim the next problem in the form of "the crumpled paper will reach the ground first" and the sentence "the paper in the form of sheets dropped, it will be hampered by air" as the data and "and fall longer" as the warrants for the claims that he made previously. $S_{B}$ students also provide their backings and qualifier through the 
sentence "acceleration of gravity applies if we ignore air resistance" and "if the two papers are dropped in a vacuum, then both papers will fall simultaneously". SB's ability to provide arguments at level 4 shows $S_{B}$ mastery of the topic/material being discussed. Sampson and Clark in their research found that there was a significant relationship between the content knowledge that students had and the quality of the arguments given (Sampson \& Clark, 2011). The next example regarding the arguments given by the students in the Newton's 1st Law argumentation session is explained as follows,

$T$ : What happens to an object (which can be a bottle filled with water) is placed on paper then the paper is pulled quickly?

$S_{C}$ : The object will remain motionless. When a bottle containing water is placed on paper then we pull the paper quickly so the bottle does not move away from its position.

The argument given by $S_{C}$ students is at level 2. This is because the argument contains claims in the form of "the object will remain motionless" and the data is in the form of "when a bottle containing water is placed on paper then we pull the paper quickly so the bottle does not move away from its position". In this case, $S_{c}$ was unable to link the relationship between the data provided and the claim so the quality of the arguments given by $S_{C}$ was still classified as a weak arguments. This seems to be consistent with Ryu \& Sandoval's statement that when students have provided data, students often fail to make the right relationship between claims and data (Ryu \& Sandoval, 2012).

\section{Descriptive Analysis of Written and Oral Argumentation Ability}

After analyzing the results of the students' scientific arguments both in written and spoken, we tried to compare the quality of both (written - oral) arguments to the same student. Here, we present examples of the cases that we encountered when comparing the ability of the written and oral argumentation in Table 3 . We only made this comparison to some students because fewer students can give arguments verbally.

Table 3. Comparison of the quality of the written and oral scientific arguments.

\begin{tabular}{|c|c|c|c|}
\hline \multirow{2}{*}{ Students } & \multirow{2}{*}{ Material } & \multicolumn{2}{|c|}{$\begin{array}{l}\text { Quality of Scientific } \\
\text { Argumentation }\end{array}$} \\
\hline & & Written & Oral \\
\hline$S_{D}$ & Newton's 1 Law & Level 2 & Level 2 \\
\hline$S_{E}$ & Newton's 1 Law & Level 2 & Level 3 \\
\hline$S_{F}$ & Newton's 2 Law & Level 3 & Level 3 \\
\hline$S_{G}$ & Newton's 2 Law & Level 2 & Level 4 \\
\hline$S_{H}$ & Newton's 3 Law & Level 1 & Level 4 \\
\hline$S_{I}$ & Newton's 3 Law & Level 1 & Level 1 \\
\hline
\end{tabular}

Table 3 shows that a small portion of the students' scientific arguments get the same level of quality between written and oral argumentation (as shown by $S_{D}, S_{F}$, and $S_{I}$ students) while other students show that oral scientific arguments are higher than written scientific arguments. This result was supported by several studies that claim that the students' written arguments had fewer components and were weaker than the oral arguments (Berland \& Mcneill, 2010; Ulpa et al., 2014). This is possible because the results of the students' written arguments are done individually, and the results of the students' oral arguments are the result of group discussions. Arranging arguments individually makes students do not have the opportunity to evaluate arguments from different views and can not exchange ideas or information to build knowledge, which 
causes the level of quality of students' written arguments in this study to be lower than the oral arguments they have. Meanwhile, students frame the arguments in different ways so that when they are involved in groups, they will act in their ways to share ideas (Berland \& Hammer, 2012). Several factors can increase the quality of students' written and oral arguments and have a positive relationship, i.e the involvement of students in scientific writing in several class discussions that focus on group argumentation presentations, as well as an increase in awareness about the benefits of peer criticism (Chen et al., 2016). In their research, Evagorou \& Osborne also added several factors that contributed to the success of students in making arguments in groups, i.e 1) engaging in exploration talks and negotiating understanding during learning, 2) the existence of student activities to be involved in asking questions to clarify evidence, understand and sharing ideas among group members 3) there is a discussion about the structure and understanding of the argument (Evagorou \& Osborne, 2013). Based on this, there are several benefits of group argumentation activities i.e, it can increase motivation and learning material, can improve general and specific argumentation skills, and improve practice in building knowledge (Hmelo-Silver et al., 2013).

\section{CONCLUSIONS}

The 5E Learning Cycle treatment has been implemented into science learning to examine the effects of the treatment on the students' scientific argumentation skills in both written and oral senses. Several data collection methods were used during the study, including academic tests at the beginning and the end of each learning session and descriptive tests. The results are reported as several concluding remarks as follows. Firstly, the students are allowed to practice their scientific argumentation skills during the 5E Learning Cycle implementation. The skills in giving scientific argument, after the implementation, are found to improve, relatively compared to those before. This is supported by the N-Gain score of 0.56 achieved, indicating an improved ability in these skills. Secondly, the enhanced quality of students' argumentation skills during science learning is shown by percentages of more than $75 \%$ obtained for all the five learning activities, which is classified as well-performed. Thirdly, the oral skill is found to be better than the written one because the results of the students' written arguments were done individually, and the results of the students' oral arguments were the result of group discussions. This proves that group discussions have a good contribution to students' scientific argumentation skills. There are several limitations to this study. First, this study has a small $\mathrm{N}$ score (number of participants $(\mathrm{N})=32$ students), so the results of this study need to be interpreted with caution. Participants in this study only consisted of a group of students in the same class. The presence of inconsistencies in attendance and submission of assignments also resulted in reduced data availability and limited scope of analysis. The next limitation is that not all students can provide oral scientific arguments during the argumentation session. This causes this study to only be able to compare the results of several written and oral arguments made by the same students. Future research is expected to use more data to obtain more detailed results regarding the ability of oral and written scientific argumentation. The existence of learning models and different material topics and supporting learning instruments will contribute to introducing scientific argumentation in science classrooms. 


\section{ACKNOWLEDGEMENTS}

The authors would like to thank anonymous reviewer(s) of IJORER for good comments on the manuscript draft, making it to improve in quality appropriate for publication.

\section{REFERENCES}

Berland, L. K., \& Hammer, D. (2012). Framing for scientific argumentation. Journal of Research in Science Teaching, 49(1), 68-94. https://doi.org/10.1002/tea.20446

Berland, L., \& Mcneill, K. (2010). A learning progression for scientific argumentation: Understanding student work and designing supportive instructional contexts. Science Education, 94, 765-793. https://doi.org/10.1002/sce.20402

Cahyaningrum, F., Andayani, A., \& Saddhono, K. (2018). Peningkatan keterampilan menulis argumentasi melalui model think pair share dan media audiovisual pada siswa kelas X-10 SMA Negeri Kebakkramat. Jurnal Pendidikan dan Kebudayaan, 3(1), 261679. https://doi.org/10.24832/jpnk.v3i1.605

Chan, V. (2011). Teaching Oral communication in undergraduate science: Are we doing enough and doing it right? Journal of Learning Design, 4(3), 71-79.

Chen, Y.-C., Hand, B., \& Park, S. (2016). Examining elementary students' development of oral and written argumentation practices through argument-based inquiry. Science \& Education, 25(3), 277-320. https:/ / doi.org/10.1007/s11191-016-9811-0

Chen, Y.-C., Mineweaser, L., Accetta, D., \& Noonan, D. (2018). Connecting argumentation to 5E inquiry for preservice teachers. Journal of College Science Teaching, 47, 22-28.

Demircioglu, T., \& Ucar, S. (2015). Investigating the effect of argument-driven inquiry in laboratory instruction. Educational Sciences: Theory $\mathcal{E}$ Practice, 15, 267-283. https://doi.org/10.12738/estp.2015.1.2324

Eemeren, F. H. van, \& Henkemans, A. F. S. (2016). Argumentation: Analysis and evaluation. Taylor \& Francis.

Erduran, S., Simon, S., \& Osborne, J. (2004). TAPping into argumentation: Developments in the application of Toulmin's argument pattern for studying science discourse. Science Education, 88(6), 915-933. https://doi.org/10.1002/sce.20012

Ernawati, M. D. W., Muhammad, D., Asrial, A., \& Muhaimin, M. (2019). Identifying creative thinking skills in subject matter bio-chemistry. International Journal of Evaluation and Research in Education (IJERE), 8(4), 581-589. https:// doi.org/10.11591/ijere.v8i4.20257

Evagorou, M., \& Osborne, J. (2013). Exploring young students' collaborative argumentation within a socioscientific issue. Journal of Research in Science Teaching, 50, 209-237. https://doi.org/10.1002/tea.21076

Faizah, L., Probosari, R. M., \& Karyanto, P. (2018). Penerapan problem based learning untuk meningkatkan keterampilan argumentasi lisan siswa kelas XI pada pembelajaran biologi. Jurnal Biotek, 6(2), 1-12. https://doi.org/10.24252/jb.v6i2.6395

Faize, F. A., Husain, W., \& Nisar, F. (2018). A critical review of scientific argumentation in science education. EURASIA Journal of Mathematics, Science and Technology Education, 14, 475-483. https://doi.org/10.12973/ejmste/80353 
Fauziya, D. S. (2016). Pembelajaran kooperatif melalui teknik duti-duta dalam meningkatkan kemampuan menulis argumentasi. Riksa Bahasa: Jurnal Bahasa, Sastra, dan Pembelajarannya, 2(2), Article 2. https:/ / doi.org/10.17509/rb.v2i2.9556

Ferretti, R. P., \& Lewis, W. E. (2019). Best practices in teaching argumentative writing. In $S$. Graham, C. A. MacArthur, \& J. Fitzgerald (Eds.), Best practices in writing instruction (3rd ed., pp. 135-161). Guilford Press.

Hake, R. H. R., \& Reece, J. G. (1999). Analyzing change/gain scores.

Hand, B., \& Choi, A. (2010). Examining the impact of student use of multiple modal representations in constructing arguments in organic chemistry laboratory classes. Research in Science Education, 40(1), 29-44. https://doi.org/10.1007/s11165-0099155-8

Hartidini, S., Syahrul R, \& Ratna, E. (2018). Pengaruh strategi pembelajaran inkuiri berbantuan media audiovisual terhadap keterampilan menulis karangan argumentasi siswa kelas X SMA Negeri 2 Lengayang kabupaten pesisir selatan. Pendidikan Bahasa Indonesia, 7(1), 63-69. https://doi.org/10.24036/9543-019883

Heng, L. L, Johari, B. S., \& Yazid, A. M. (2012). Penguasaan penaakulan saintifik pelajar pendidikan opsyen sains terhadap konsep Asid and Bes (The mastery of scientific reasoning among science option education students on acids and bases concept). International Seminar in Science and Mathematics Education, Universiti Teknologi Malaysia, Skudai.

Heng, Lee Ling, Surif, J., \& Seng, C. H. (2015). Malaysian students' scientific argumentation: Do groups perform better than individuals? International Journal of Science Education, 37(3), 505-528. https:/ / doi.org/10.1080/09500693.2014.995147

Hmelo-Silver, C. E., Chinn, C. A., \& Chan, C. (2013). The international handbook of collaborative learning. New York: Routledge.

Hulu, V. T., \& Sinaga, T. R. (2019). Analisis data statistik parametrik aplikasi SPSS dan statical (Sebuah Pengantar Untuk Kesehatan). Jakarta: Yayasan Kita Menulis.

Ismail, H. F. (2018). Statistika untuk penelitian pendidikan dan ilmu-ilmu sosial. Jakarta: Kencana.

Jiménez-Aleixandre, M.P., \& Puig, B. (2012). Argumentation, evidence evaluation and critical thinking. In B. J. Fraser, K. Tobin, \& C. J. McRobbie (Eds.), Second International Handbook of Science Education (pp. 1001-1015). Springer Netherlands. https://doi.org/10.1007/978-1-4020-9041-7_66

Kaçar, D.A. (2013). The effect of 5E learning cycle model in teaching trigonometry on students' academic achievement and the permanence of their knowledge. 4(1), 15.

Kaniawati, D.S., Kaniawati, I., \& Suwarma, R. (2015). Study literasi pengaruh pengintegrasian pendekatan stem dalam Learning Cycle 5E terhadap kemampuan pemecahan masalah siswa pada pembelajaran fisika. Seminar Nasional Fisika, 3948.

Kivunja, C. (2014). Innovative pedagogies in higher education to become effective teachers of 21st century skills: Unpacking the learning and innovations skills domain of the new learning paradigm. International Journal of Higher Education, 3(4), 37. https://doi.org/10.5430/ijhe.v3n4p37

Kizilaslan, A. (2019). The development of science process skills in visually impaired students: Analysis of the activities. International Journal of Evaluation and Research in Education (IJERE), 8(1), 90-96. https://doi.org/10.11591/ijere.v8i1.17427

Kuhn, D., Hemberger, L., \& Khait, V. (2017). Argue with Me: Argument as a path to developing students' thinking and writing. New York: Routledge. 
Kulatunga, U., Moog, R., \& Lewis, J. (2014). Use of Toulmin's argumentation scheme for student discourse to gain insight about guided inquiry activities in college chemistry. Journal of College Science Teaching, 43, 78-86. https://doi.org/10.2505/4/jcst14_043_05_78

Kurniasari, I. S. (2017). Penerapan model pembelajaran argument driven inquiry (ADI) untuk melatihkan kemampuan argumentasi ilmiah siswa pada materi usaha dan energi. Inovasi Pendidikan Fisika, 6(3). https://jurnalmahasiswa.unesa.ac.id/index.php/inovasi-pendidikanfisika/article/view/20276

Larson, L., \& Miller, T. (2011). 21st century skills: Prepare students for the future. Kappa Delta Pi Record, 47, 121-123. https://doi.org/10.1080/00228958.2011.10516575

Mcneill, K. (2011). Elementary students' views of explanation, argumentation, and evidence, and their abilities to construct arguments over the school year. Journal of Research in Science Teaching, 48, 793-823. https:/ / doi.org/10.1002/tea.20430

McNeill, K.L., \& Krajcik, J.S. (2008). Assessing middle school students' content knowledge and reasoning through written scientific explanations. In Coffey, J., Douglas, $R$. ., $\mathcal{E}$ Stearns, C. (Eds.), Assessing science learning: Perspectives from research and practice. National Science Teachers Association Press.

McNeill, K. L., \& Martin, D. M. (2011). Claims, evidence, and reasoning: demystifying data during a unit on simple machines. Science and Children, 48(8), 52-56.

National center for education statistics. (2012). The Nation's Report Card: Writing 2011: Executive Summary. National Center for Education Statistics. https://nces.ed.gov/nationsreportcard/pubs/main2011/2012470.aspx

Ni'amah, I.W., Poerwanti, J.I., \& Winarni, R. (2017). Peningkatan keterampilan menulis argumentasi melalui model pembelajaran SAVI (Somatic Auditory Visualization Intellectualy) pada siswa sekolah dasar. Jurnal Didaktika Dwija Indria, 5(8).

Putri, S.S., Japar, M., \& Bagaskorowati, R. (2019). Increasing ecoliteracy and student creativity in waste utilization by using models in project based learning social studies learning. International Journal of Evaluation and Research in Education (IJERE), 8(2), 255-264. https://doi.org/10.11591/ijere.v8i2.18901

Riduwan. (2015). Skala pengukuran variabel-variabel penelitian. Alfabeta.

Robertshaw, B., \& Campbell, T. (2013). Constructing arguments: Investigating preservice science teachers' argumentation skills in a Socio-Scientific Context. Science Education International, 24(2), 195-211.

Roviati, E., \& Widodo, A. (2019). Kontribusi argumentasi ilmiah dalam pengembangan keterampilan berpikir kritis. Titian Ilmu: Jurnal Ilmiah Multi Sciences, 11(2), 56-66. https://doi.org/10.30599/jti.v11i2.454

Ryu, S., \& Sandoval, W. (2012). Improvements to elementary children's epistemic understanding from sustained argumentation. Science Education, 96, 488-526. https://doi.org/10.1002/sce.21006

Sampson, V. (2014). Argument-driven inquiry in Biology: Lab investigations for grades 9-12. NSTA Press.

Sampson, V., \& Clark, D. (2011). A comparison of the collaborative scientific argumentation practices of two high and two low performing groups. Research in Science Education, 41, 63-97. https:/ / doi.org/10.1007/s11165-009-9146-9

Santoso, S. (2019). Menguasai SPSS versi 25. Jakarta: Elex Media Komputindo.

Si, G. P., M. (2015). Kupas tuntas data penelitian dengan SPSS 22. Elex Media Komputindo. 
Tama, N.B. (2015). Penerapan project based learning untuk meningkatkan kemampuan argumentasi tertulis siswa kelas X MIPA 2 SMA Negeri 5 Surakarta pada materi ekosistem. Jurnal Inovasi dan Pembelajaran Fisika, 2(2), 170-176.

Toulmin, S.E. (2003). The uses of argument. Cambridge University Press.

Ulpa, M., Abdurrahman, A., \& Wahyudi, I. (2014). Perbandingan hasil belajar fisika ditinjau dari kemampuan argumentasi oral dan tertulis. Jurnal Pembelajaran Fisika, 2(3). http://jurnal.fkip.unila.ac.id/index.php/JPF/article/view/4431

Wahdan, W. Z., Sulistina, O., \& Sukarianingsih, D. (2017). Analisis kemampuan berargumentasi ilmiah materi ikatan kimia peserta didik SMA, MAN, dan Perguruan Tinggi Tingkat I. J-PEK (Jurnal Pembelajaran Kimia), 2(2), 30-40. https://doi.org/10.17977/um026v2i22017p030

Walker, J., \& Sampson, V. (2013). Learning to argue and arguing to learn: Argumentdriven inquiry as a way to help undergraduate chemistry students learn how to construct arguments and engage in argumentation during a laboratory course. Journal of Research in Science Teaching, 50, 561-596. https://doi.org/10.1002/tea.21082

\footnotetext{
*Valensa Yossyana, M.Pd (Corresponding Author)

Science Education Study Program, Postgraduate Program,

The State University of Surabaya, Indonesia

Rektorat Unesa Street, Lidah Wetan, Lakarsantri Sub-District,

Surabaya, East Java, 60213

Email: valensa.18034@mhs.unesa.ac.id
}

\author{
Nadi Suprapto, S.Pd., M.Pd., Ph.D \\ Department of Physics, \\ The State University of Surabaya, Indonesia \\ Ketintang Street, Ketintang, Gayungan Sub-District, \\ Surabaya, East Java, 60231 \\ Email: nadisuprapto@unesa.ac.id
}

Tjipto Prastowo, Ph.D

Department of Physics,

The State University of Surabaya, Indonesia

Ketintang Street, Ketintang, Gayungan Sub-District,

Surabaya, East Java, 60231

Email: tiiptoprastowo@unesa.ac.id 